\title{
The potential of amylase enzyme activity against bacteria isolated from several lakes in East Java, Indonesia
}

\author{
INDAH KHOIRUN NISA, SITORESMI PRABANINGTYAS`, BETTY LUKIATI, RINA TRITURANI SAPTAWATI, \\ ACHMAD RODIANSYAH \\ Department of Biology, Faculty of Mathematics and Natural Sciences, Universitas Negeri Malang. Jl. Semarang No. 5, Malang 65145, East Java, \\ Indonesia. Tel.: +62-341-567382, ’email: sitoresmi.prabaningtyas.fmipa @um.ac.id
}

Manuscript received: 27 September 2020. Revision accepted: 8 December 2020.

\begin{abstract}
Nisa IK, Prabaningtyas S, Lukiati B, Saptawati RT, Rodiansyah A. 2021. The potential of amylase enzyme activity against bacteria isolated from several lakes in East Java, Indonesia. Biodiversitas 22: 42-49. Indonesia is one country that has water resources having an abundance of microbial diversity, but not explored massively. This study aims to measure the amylase activity quantitatively from 53 amylolytic bacterial isolates from Ranu Pani, Ranu Regulo, Ranu Grati, and Ngebel Lake; also it identifies the isolate with the highest amylase enzyme activity. The amylase enzyme activity test calculates with DNS (Dinitrosalycylic acid) method, molecular identification of the highest bacterial isolate is based on the $16 \mathrm{~S}$ rRNA gene. Its relationship is determined through the phylogenetic tree with the Neighbor-Joining (NJ) method. The results showed that the fifty-three bacterial isolates have amylase activity about 0.000 0.016 units $/ \mathrm{mL}$. The KN bacterial isolate from Ranu Ngebel was the highest amylase activity, producing enzyme around 0.016 units $/ \mathrm{mL}$, while isolate G20 from Ranu Grati was the lowest, reaching about $0.0001 \mathrm{Unit} / \mathrm{mL}$. Based on the morphological and molecular identification, the $\mathrm{KN}$ bacterial isolate is classified as the Bacillus cereus group with 99.4-100\% sequence similarity, closely related to Bacillus paramycoides (NR 157734.1).
\end{abstract}

Keywords: 16S rRNA gene, amylolytic bacteria, DNS method, lakes, East Java

\section{INTRODUCTION}

Amylolytic bacteria can produce amylase that can break down starch into simple sugars through the stages of gelatinization, liquidation, and saccharification (Kaneko, 2014; Silaban et al. 2020). Many amylolytic bacteria could grow optimally on materials containing starch. This group of bacteria can be found anywhere, such as in lakes. Amylase enzymes produced from amylolytic bacteria are widely used in various fields because this bacterial culture grows so fast that it requires a short amount of time to produce amylase (Bhattacharjee et al. 2019)

$\alpha$-Amylase is one of the most popular and important forms of amylase in the industrial sector (Souza 2010). This enzyme catalyzes the hydrolysis of starch into glucose, maltose, and maltotriose specified in the $\alpha-1,4-$ glycosidic bond, and this enzyme can break down terminal glucose residues or $\alpha$-1,6-linkage (Lestari et al. 2013). $\alpha$ Amylase can be produced from a variety of microorganisms, but the genus Bacillus spp. used commercially in various industrial products includes detergents, food, textiles, paper, biofuels, and starch conversion (Bhattacharjee et al. 2019)

In the microalgae culture, this type of bacteria is very beneficial because it can degrade substrates easily, then the product can be utilized by algae for its growth, exchanging metabolites, and causing microalgae to be more resistant to the environmental disorders (Souza 2010; Lian et al. 2018). The microbial consortium or the use of symbiotic mutualism of several microbes provides very beneficial results compared to a single microbe; this is because the enzymes of each type of microbe can complement each other for growth (Fakhimi et al. 2020).

The quantitative method most often used in determining amylase activity is the DNS (dinitro salicylic acid) method using a spectrophotometer at a wavelength of $540 \mathrm{~nm}$ (Miller 1959; Keharom et al. 2016). At the same time, bacterial characterization is carried out: identification of colony morphology and bacterial cells and using molecular techniques (DNA barcode). DNA barcode is a promising, accurate, inexpensive, fast, and sophisticated method for species identification (Srinivasan et al. 2015; Hanner et al. 2011). DNA barcode uses the $16 \mathrm{~S}$ rRNA gene that is useful for bacterial population characterization, taxonomy, phylogeny, and species identification. The use of $16 \mathrm{~S}$ rRNA gene sequences is based on gene function has not changed over time, and the 16S rRNA gene is large enough (1500 bp) for informative purposes (Johnson et al. 2019). The determination of the sample's genus and species is based on the similarity index (IS). Similarity or sequence similarity of $16 \mathrm{~S}$ rRNA $95 \%$ recommended for genus classification and $98.7 \%$ for species (Rossi-Tamisier et al. 2014).

Indonesia is a country that has rich biodiversity and a large area of water but has not yet explored much of amylolytic bacteria as amylase enzyme producers in the waters. The use of 4 lakes (Ranu Pani, Ranu Regulo, Ranu Grati, and Ngebel Lake) is because the 4 lakes are aquatic ecosystems in Indonesia, especially in East Java. In Ranu Pani and Ranu Regulo occur algae blooms, which can 
indicate many potential bacteria there, and differences in environmental baseline so that it needs to be studied. The purposes of this study were to test the amylase enzyme activity quantitatively with 53 amylolytic bacterial isolates obtained from the previous study (Basitoh 2018), finding bacterial isolates that have the highest potential for amylase enzyme activity, and identify the highest isolate producing amylase enzyme based on morphology and 16S rRNA gene barcode.

\section{MATERIALS AND METHODS}

\section{Isolates culture and pre-culture}

A total of fifty-three bacterial isolates from Ranu Pani, Ranu Regulo, Ranu Grati, and Ngebel Lake have the potency to degrade starch based on the clear-zone method were selected based on the previous study (Basitoh 2018) (data not shown). Those isolates were cultured in YPSs media (Arman et al. 2020) composed of $0.1 \mathrm{~g}$ yeast extract (Merck, USA), $0.25 \mathrm{~g}$ peptone (Merck, USA), $0.15 \mathrm{~g}$ $\mathrm{KH}_{2} \mathrm{PO}_{4}, 0.025$ g $\mathrm{MgSO}_{4} .2 \mathrm{O}, 0.005 \mathrm{CaCl}_{2} .2 \mathrm{H}_{2} \mathrm{O}, 10 \mathrm{~g}$ agar, and $1 \mathrm{~g}$ starch in $1000 \mathrm{~mL} \mathrm{H}_{2} \mathrm{O}$. Those compounds for YPSs media were mixed in Erlenmeyer then sterilized at $15 \mathrm{Psi}, 121^{\circ} \mathrm{C}$ for 15 minutes using an autoclave. The isolates stock were pre-cultured about one ose into YPSs media for enzyme production.

\section{Amylase enzyme production}

The crude amylase enzyme was produced in liquid YPSs media. The isolates were inoculated into YPSs liquid media then incubated for $3 \times 24 \mathrm{~h}$ at room temperature until reaching a density of 0.5 . The cultures that have OD at 0.5 was taken about $5 \mathrm{~mL}$ then transferred into a $20 \mathrm{~mL}$ new YPSs liquid media. Those cultures were incubated for $3 \mathrm{x}$ $24 \mathrm{~h}$ in an incubator shaker at $130 \mathrm{rpm}$. The unpurified enzyme was harvested using centrifugation at 10,000 rpm for $5 \mathrm{~min}, 4^{\circ} \mathrm{C}$. The supernatant as a crude enzyme was measured with the DNS method to determine amylase activity (Amri et al. 2010; Miller 1959).

\section{Amylase enzyme activity test}

The amylase activity of the crude enzyme was conducted by using the DNS method (Miller 1959). Approximately $0.5 \mathrm{~mL}$ of the crude enzyme was added with $0.5 \mathrm{~mL}$ of substrate $(1 \%$ dissolved starch in $0.2 \mathrm{M}$ phosphate buffer solution $\mathrm{pH} 7$ ). Those solutions were mixed in a microtube $(1.5 \mathrm{~mL})$ then incubated for $10 \mathrm{~min}$ at $40^{\circ} \mathrm{C}$. After incubation, the reaction was stopped by the addition of $2 \mathrm{~mL}$ of 3.5-dinitro salicylic-acids (DNS), heated in boiling water for $5 \mathrm{~min}$ then cooled in ice water for 20 minutes. The reducing glucose as products from amylase activity was measured at a wavelength of $540 \mathrm{~nm}$, the DNS reagent used for blank (Naiola 2008). Amylolytic enzyme activity values were obtained by using a linear line equation to determine the concentration of glucose in the YPSs medium and proceed according to the formula (Kombong 2004):

$$
\mathrm{EA}=\frac{\mathrm{C}}{\text { WM Product } \mathrm{xt}} \mathrm{x} \frac{\mathrm{TV}}{\mathrm{VE}}
$$

Where: EA: Enzyme Activity (Units $/ \mathrm{mL}$ ), C: Concentration Of Glucose, WM: Weight Molecule Of Glucose: $180 \mathrm{~g} / \mathrm{mol}$, t: Time Of Incubation (minutes), TV: Total Volume Of Enzim-Substrat (mL), VE: Volume Of Enzim (mL)

\section{Glucose standard curve}

The glucose standard curve was made with various concentrations, as follows: 0, 20, 30, 40, 50, and $60 \mathrm{ppm}$. Stock glucose with concentration $100 \mathrm{ppm}$ diluted into desired concentration with the addition of distilled water. DNS reagent about $1 \mathrm{~mL}$ into glucose solution and heated in boiling water for $5 \mathrm{~min}$ until the solution was red-brown, then $1 \mathrm{~mL}$ of $40 \% \mathrm{~K}-\mathrm{Na}$-Tatrat solution was added. After the solution has cooled, the distilled water was added until the final volume becomes $10 \mathrm{~mL}$ and then homogenized. The absorbance for the glucose standard curve was measured with a UV-Vis spectrophotometer at $540 \mathrm{~nm}$ (Miller 1959).

\section{Phenotypic characterization}

The phenotypic characterization of bacterial isolates was carried out by identification of colony morphology (color, the shape of plate medium colony, oblique colony shape, the edge of the colony, elevation, shiny/ gloomy, colony diameter, colony density) and bacterial cells (gram type, capsule type, spore shape, bacterial motion, and type of respiration) (Bhattacharjee et al. 2019). The growth medium used for respiration observation was the Nutrient Broth media (NB).

\section{DNA isolation}

The highest amylolytic was identified using DNA barcoding method using 16S rRNA sequence. The highest amylolytic potential bacterial was cultured in Nutrient Broth (NB) for $24 \mathrm{~h}$ at $37^{\circ} \mathrm{C}$. $2.5 \mathrm{ml}$ of pure bacterial culture was centrifuged for $5 \mathrm{~min}$ at $7500 \mathrm{rpm}$, the pellets used for gDNA isolation. gDNA from the sample was isolated following the manufacturer's protocol for bacterial isolation using the QIAmp DNA Mini Kit (Qiagen, Germany) (www.qiagen.com).

\section{PCR of 16S genes and DNA sequencing}

The 16S rRNA gene amplification process was carried out with the PCR kit of the brand Taq PCR Master Mix Kit from Qiagen, Germany. The primers used included a forward primer 27F (5'-AGAGTTTGATCMTGGCTCAG'3) and a reverse primer 1492R (5'TACGGYTACCTTGTTACGACTT-'3) (Tomar et al. 2019) The PCR profile reaction as follow: initial denaturation of $94^{\circ} \mathrm{C} / 3 \mathrm{~min}$, denaturation of $94^{\circ} \mathrm{C} / 1 \mathrm{~min}$, annealing $50^{\circ} \mathrm{C} / 30 \mathrm{~s}$, extension $72^{\circ} \mathrm{C} / 90 \mathrm{~s}$, final extension $72^{\circ} \mathrm{C} / 10 \mathrm{~min}$, and hold $4^{\circ} \mathrm{C}$ for 30 cycles. The PCR amplicons were visualized using electrophoresis with $1 \%$ agarose gel, 100 Volts, $200 \mathrm{~A}$ for $30 \mathrm{~min}$. The results of the electrophoresis were examined using a UV transilluminator (www.qiagen.com). 


\section{Phylogenetic analysis}

The sequencing result data was read with Finch TV and Bioedit software. The data were analyzed descriptively with DNA Baser to obtain a consensus sequence. The multiple alignments were conducted with blast nucleotide program or BLAST (Basic Local Alignment Search Tool) from NCBI (www.ncbi.nlm.nih.gov). The alignment data were downloaded in the form of .fasta (Fasta file) and .gb files (GenBank file). The phylogenetic analysis was constructed using MEGA.6 software with NeighborJoining (NJ) (Uncu et al. 2015) and bootstrap test 1000 replications (Chong and Choo 2011)

\section{RESULTS AND DISCUSSION}

\section{Amylase activity assay}

A total of fifty-three isolates were used in this study to check their ability to hydrolyze amylum (starch) obtained from Ranu Pani, Ranu Regulo, Ranu Grati, and Ngebel Lakes. Table 1 showed the ten highest isolates that can hydrolyze amylum with incubation $72 \mathrm{~h}$, while data from all isolates can be seen in Table S1. The reducing sugar concentration (ppm) was a class of carbohydrates that reduces electron-receiving compounds. The amylase enzyme activity (Units $/ \mathrm{mL}$ ) is the amount of $\mu \mathrm{mol}$ glucose produced from starch hydrolysis by $1 \mathrm{~mL}$ of crude amylase extract during the incubation period. The indicator of amylase enzyme activity by amylolytic bacteria is the level of reducing sugar produced. Glucose as a standard reducing sugar was made a standard curve, with a linear line equation $y=0.0064 x-0,0008$ with $\mathrm{R} 2=0.9947$ (Figure 1 ). Measurement of amylase enzyme activity can be done using a linear line equation to determine the glucose concentration in the YPSs medium and calculated according to the (Kombong 2004).

KN's highest amylolytic bacteria activity isolate about $42.781 \mathrm{ppm}$ glucose as the product with enzyme concentration 0.016 units $/ \mathrm{mL}$. This result also showed the different amylolytic activity compared with semiquantitative assay with a clear zone method (Basitoh 2018) (data not shown). Measuring the amylase activity of 10 bacterial isolates with high amylolytic potential (starting from 0.010 units $/ \mathrm{mL}$ to 0.016 units $/ \mathrm{mL}$ ) is presented in Table 1. KN isolates from Ngebel Lake had the highest amylase activity by 0.016 units $/ \mathrm{mL}$, while G20 isolates from Ranu Grati with the lowest by 0.000 units/mL (Table S1).

Enzyme activity in this study was measured using DNS. In a basic atmosphere, redox reactions occur between reducing sugars and DNS, which lies behind DNS's basic principle. The sugar aldehyde group oxidizes to carboxyl while the reduced DNS forms 3 -amino and 5 nitro salicylic. The 3-nitro $\left(\mathrm{NO}_{2}\right)$ group of 3.5 dinitro salicylic acid is reduced to the amino group $\left(\mathrm{NH}_{2}\right)$ on heating with reducing sugars. The size of the amylase enzyme activity is influenced by reducing sugar in the sample. The more reducing sugars are contained in the sample, the more 3amino-5-nitrosalicylic acid molecules are formed so that the absorption of electromagnetic waves is higher (Sazci et al. 1986).

DNS reagents can work with supporting components, namely KNa-Tartarat (Rochell salt), phenol, sodium bisulfite $\left(\mathrm{Na}_{2} \mathrm{SO}_{3}\right)$, and sodium hydroxide $(\mathrm{NaOH})$. 3,5dinitro salicylic acid acts to reduce glucose in an alkaline atmosphere, which is assisted by sodium hydroxide $(\mathrm{NaOH}), \mathrm{KNa}-$ Tartarat (Rochell salt) performs to eliminate the effect of confounding compounds so that the color complex is stable, phenol functions for stabilization of the color form, and sodium bisulfite $\mathrm{Na}_{2} \mathrm{SO}_{3}$ ) functions to eliminate the effect of dissolved oxygen which can oxidize glucose products (Miller 1959).

The study results showed that the value of amylase enzyme activity of bacterial isolates from Ranu Pani, Ranu Regulo, Ranu Grati, and Ngebel Lake varied between 0.010-0.016 units/mL. KN bacterial isolates from Ngebel Lake had the highest amylase enzyme activity of 0.016 units/mL, while G20 bacterial isolates from Ranu Grati had the lowest amylase enzyme activity about 0.000 units $/ \mathrm{mL}$. Bacterial isolates originating from Ngebel Lake have the highest amylase enzyme activity because the abiotic environment supports and has a characteristic on its environmental baseline.

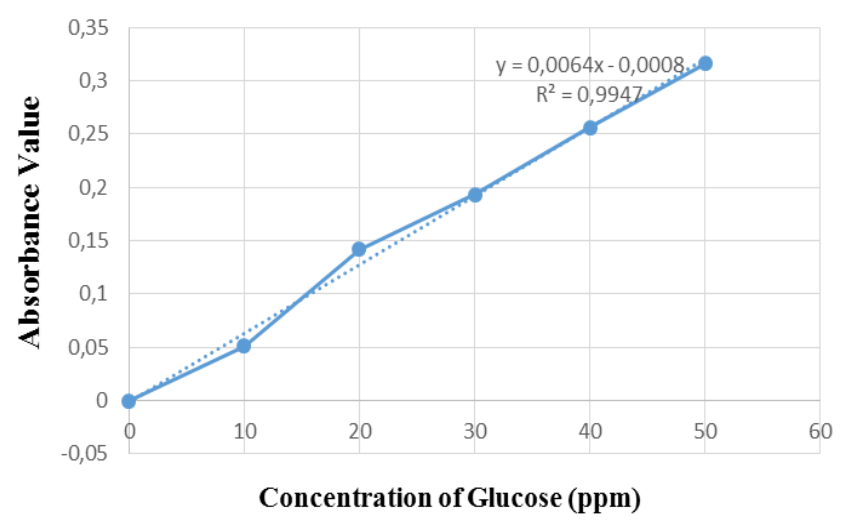

Figure 1. Equations of the Linear Curve for Glucose Standards

Table 1. The value of amylase enzyme activity from 10 highest isolates amylolytic bacterial isolates

\begin{tabular}{llcc}
\hline $\begin{array}{c}\text { Bacterial } \\
\text { isolates }\end{array}$ & \multicolumn{1}{c}{ Sources } & $\begin{array}{c}\text { Reducing } \\
\text { sugar conc. } \\
\text { (ppm) }\end{array}$ & $\begin{array}{c}\text { Amylase } \\
\text { enzyme } \\
\text { activity } \\
\text { (units/mL) }\end{array}$ \\
\hline KN & Ngebel Lake & 42.781 & 0.016 \\
V & Ranu Pani, Regulo & 41.297 & 0.015 \\
HN & Ngebel Lake & 40.229 & 0.015 \\
G33 & Ranu Grati & 34.240 & 0.013 \\
G18 & Ranu Grati & 29.969 & 0.011 \\
D & Ranu Pani, Regulo & 28.146 & 0.010 \\
VN & Ngebel Lake & 27.469 & 0.010 \\
L & Ranu Pani, Regulo & 27.391 & 0.010 \\
G13 & Ranu Grati & 26.609 & 0.010 \\
P & Ranu Pani, Regulo & 25.984 & 0.010 \\
\hline
\end{tabular}


Protected forest slopes of Mount Wilis surround the lake with $\pm 1 \mathrm{~km}$ and residential areas (Apriani 2013). These different enzyme activities are influenced by temperature, substrate concentration, enzyme concentration, inhibitors, and $\mathrm{pH}$ (Soeka 2010). Bacterial isolates originating from Ngebel Lake have different amylase activities because Ngebel Lake has a heterogeneous environment that causes different aquatic environments in each area (Apriani 2013). Other research conducted by (Raplong et al. 2014) showed the highest enzyme activity value, reaching 2.56 units/mL from Bacillus cereus. (Dipali and Argit 2012) showed the highest enzyme activity value, reaching 1.3 units/mL, when produced in submerged fermentation using Bacillus species. The value of amylase activity in this study was smaller due to differences in hydrolysis ability that had not been optimized with temperature and $\mathrm{pH}$ on amylase production activity related to organism growth.

\section{Phenotypic characterization}

The phenotypic characterization based on colony and cell description includes colony morphology, cell morphology, gram, capsule, spore, bacterial motion, and respiration type. These phenotypic characterization data can be seen in table 2. Based on the morphological characterization of colonies and cells, $\mathrm{KN}$ bacterial isolate belongs to the Bacillus group.

\section{The 16S rRNA gene amplification products}

The amplicon products from PCR were showed a sequence length of about $1500 \mathrm{bp}$. The band of amplicon from the PCR reaction was already in Figure 2.

\section{Genotypic characterization}

The 16S rRNA sequence from $\mathrm{KN}$ isolates after sequences assembling has a length of 1441 bp (Figure 3). This sequence was aligned with the Blast nucleotide program showed that it has a similarity of $99.93 \%$ and the $16 \mathrm{~S}$ Rrna sequences in this group is very homogeneous, reaching, 99\% similarity (Table 3). Bacterial isolate $\mathrm{KN}$ is based on 16S rRNA characterization is located in one clade with Bacillus paramycoides with bootstrap score 78 (Figure 4). Bacillus paramycoides is a member of the Bacillus cereus group and the $16 \mathrm{~S}$ rRNA sequences in this group is very homogeneous, reaching, 99\% similarity (Table 3 ).

\section{Genetic distance (pairwise distance) of $\mathrm{KN}$ isolates}

The KN bacterial isolate has a genetic distance related to Bacillus paramycoides with $99.9 \%$ similarity. In our result also shows if that isolate has $>99.4$ similarities with other species in genera Bacillus (Table 3) and sequences similarity within a group is about $99.7 \%$ (homogenous). Based on table 3, bacterial isolate $\mathrm{KN}$ can conclude in one species with other Bacillus groups known as Bacillus cereus group of Bacillus cereus sensu lato (Liu et al. 2017). This group consists of $B$. anthracis, B. cereus, $B$. pseudomycoides, B. weihenstephanensis, B. mycoides, and $B$. thuringiensis (Daffonchio et al. 2000), and nine new species of $B$. cereus group, namely $B$. paranthracis, $B$. tropicus, B. albus, B. pacificus, B. mobilis, B. luti, B. nitratireducens, B. paramycoides, and B. proteolyticus (Liu et al. 2017).



Figure 2. Visualization of $16 \mathrm{~S}$ rRNA PCR products with $1 \mathrm{~kb}$ marker on 1\% Agarose Gel, 100 Volt, 200 A, for $30 \mathrm{~min}$

Table 2. Morphological Characterization of $\mathrm{KN}$ isolate

\begin{tabular}{ll}
\hline Characterization & Description \\
\hline Morphological of colonies & White \\
Colony color & Circular \\
Plate medium Colony shape & Sword \\
Oblique colony Shape & Siliat \\
Colony edge & Flat \\
Elevation & Gloomy \\
Shiny or gloomy & $2 \mathrm{~cm}$ \\
Colony diameter & Concentrated \\
Colony density & Gram-Positive \\
Gram type & Bassil \\
Bacterial form & $2 \mu \mathrm{x} 1 \mu$ \\
Bacterial size & Not encapsulated \\
Capsule type & Terminal \\
Spore location & Oval \\
Spore shape & Brown motion \\
Bacterial motion & Facultative-anaerobes \\
Respiration type & \\
\hline
\end{tabular}

Table 3. The similarity of sequences in Bacillus cereus Group

\begin{tabular}{lcccc}
\hline \multicolumn{1}{c}{ Species } & $\begin{array}{c}\text { Genetic } \\
\text { distance }\end{array}$ & $\begin{array}{c}\text { Simi- } \\
\text { larity }\end{array}$ & Group & $\begin{array}{c}\text { Similarity } \\
\text { within } \\
\text { group }\end{array}$ \\
\hline Bacterial isolate KN & - & - & B. cereus group & $99.6 \%$ \\
B. paramicoides & 0.001 & $99.9 \%$ & B. cereus group & $99.6 \%$ \\
B. albus & 0.001 & $99.9 \%$ & B. cereus group & $99.6 \%$ \\
B. cereus & 0.002 & $99.8 \%$ & B. cereus group & $99.6 \%$ \\
B. proteolyticus & 0.003 & $99.7 \%$ & B. cereus group & $99.6 \%$ \\
B. wiedmannii & 0.003 & $99.7 \%$ & B. cereus group & $99.6 \%$ \\
B. pacificus & 0.004 & $99.6 \%$ & B. cereus group & $99.6 \%$ \\
B. thuringiensis & 0.005 & $99.5 \%$ & B. cereus group & $99.6 \%$ \\
B. toyonensis & 0.005 & $99.5 \%$ & B. cereus group & $99.6 \%$ \\
B. mobilis & 0.006 & $99.4 \%$ & B. cereus group & $99.6 \%$ \\
B. paranthracis & 0.004 & $99.6 \%$ & B. cereus group & $99.6 \%$ \\
B. mycoides & 0.007 & $99.3 \%$ & B. cereus group & $99.6 \%$ \\
B. pseudomycoides & 0.005 & $99.5 \%$ & B. cereus group & $99.6 \%$ \\
Escherichia coli & 0.259 & $74.1 \%$ & Out of group & $96.7 \%$ \\
Enterobacter & 0.265 & $73.5 \%$ & Out of group & $96.7 \%$ \\
hormaechei & & & & \\
\hline & & & & \\
\hline
\end{tabular}




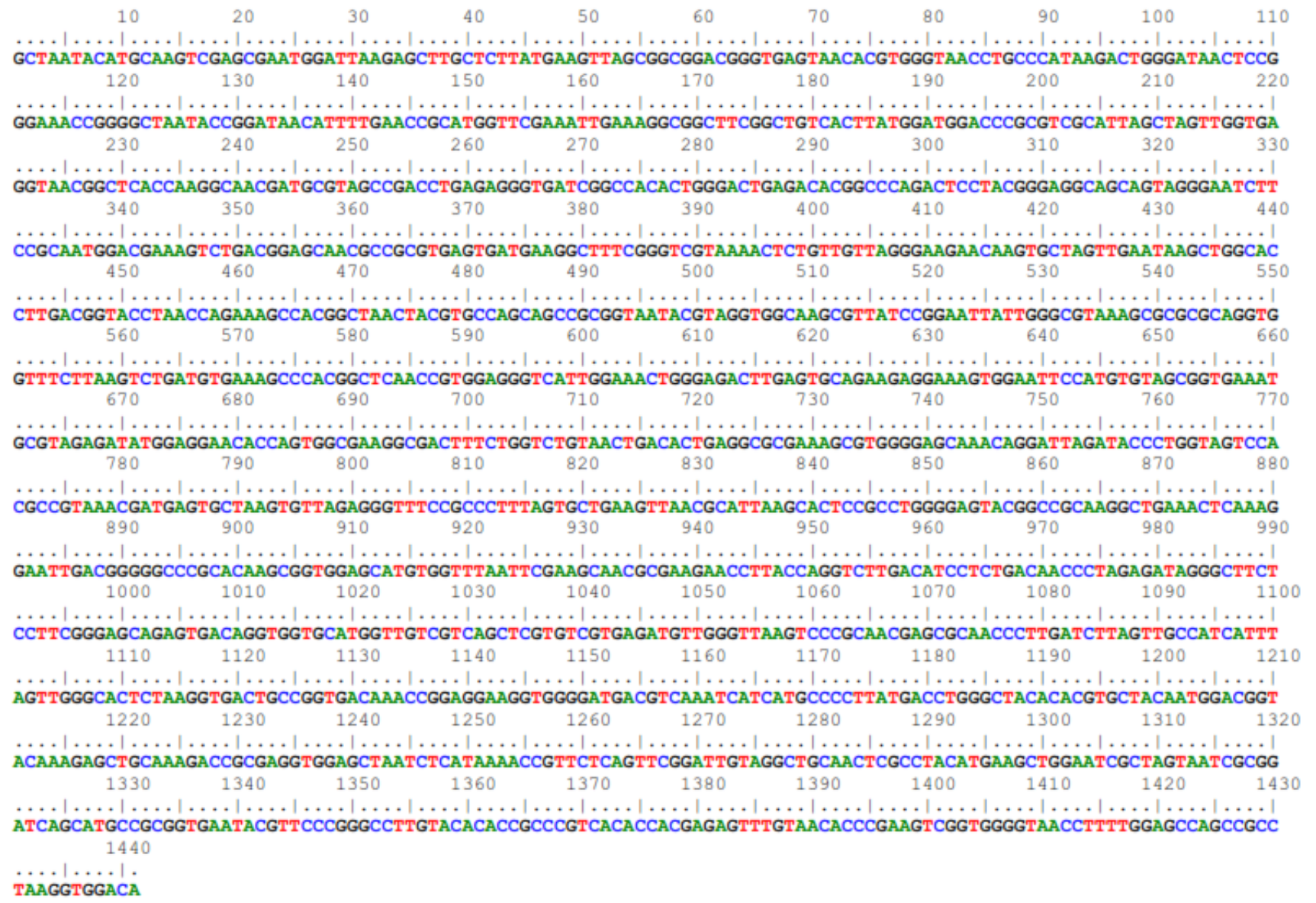

Figure 3. The $16 \mathrm{~S}$ rRNA contig sequence from KN bacterial isolate

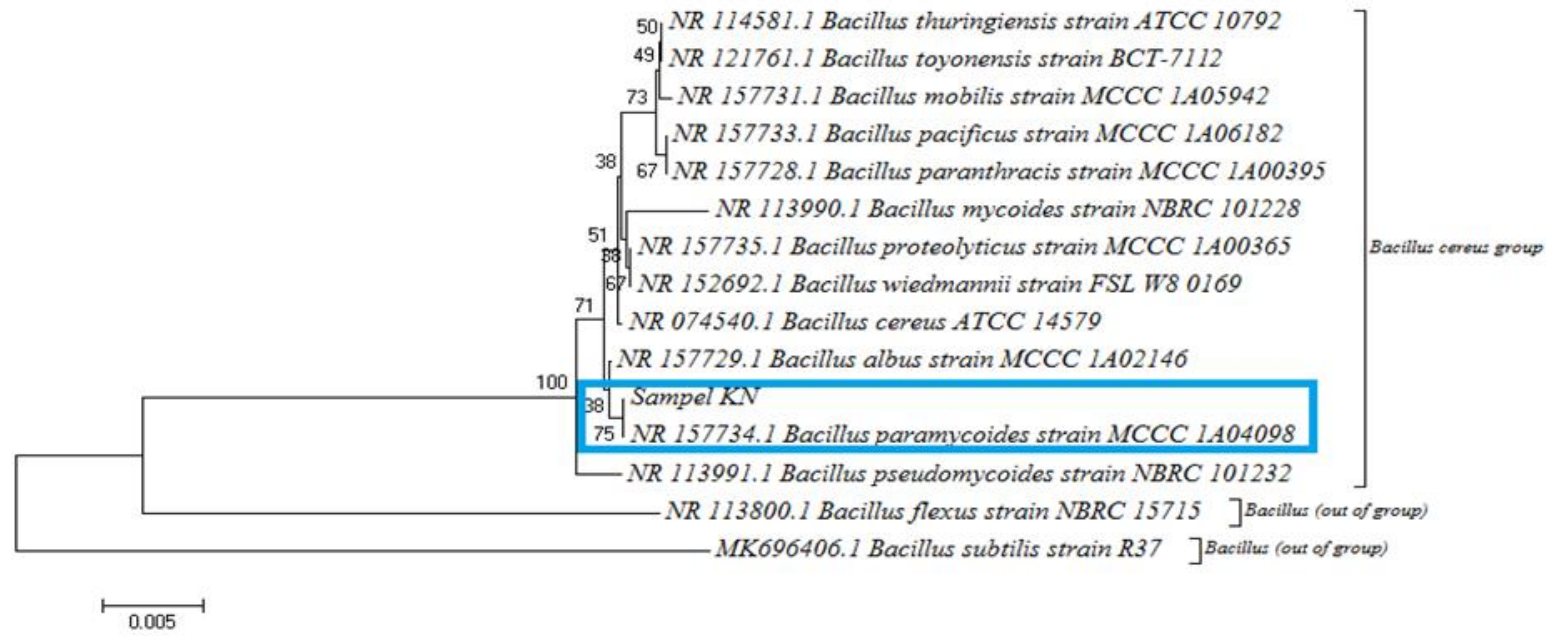

Figure 4. Evolutionary tree with Neighbor-Joining method. The KN isolate has a taxonomical position in the Bacillus cereus group. Enterobacter hormaechei and Escherichia coli were used as out of the group.

Bacillus paramycoides is a gram-positive bacteria. This species can inhibit pathogenic bacteria's growth and survive in extreme places because it produces enterotoxins that form spores, non-motile, facultative anaerobes, bacilli, or stem shaped with a diameter of 0.8-1.2 $\mu \mathrm{m}$ and length of 1.8-2,2 $\mu \mathrm{m}$. They produce amylase enzymes for hydrolyzing starch. The shape of the colony was round, opaque, and 2-3 $\mathrm{mm}$ in diameter after incubation for 48 hours at $32^{\circ} \mathrm{C}$. The catalase and oxidase test is positive. Growth occurs at $15-39^{\circ} \mathrm{C}$ with an optimal temperature of $30^{\circ} \mathrm{C}$, pH 5-9 with an optimal $\mathrm{pH}$ of 7 and with $0-5 \%$ (w / v) $\mathrm{NaCl}$ (optimum 0.5\%). Bacillus paramycoides can 
hydrolyze starch, casein, and skim milk (Liu et al. 2017; Silitonga 2019). Our morphological data seems to have similar characteristics to this species and is supported by 16S rRNA data.

Bacillus sp. in submerged fermentation was produced the highest enzyme activity of 1.3 units/mL (Dipali and Argit 2012) and B. Cereus produces the highest enzyme activity 2.56 units $/ \mathrm{mL}$ (Raplong et al. 2014). Amylase activity value in this study was found smaller due to differences in hydrolysis ability that has not been optimized with temperature and $\mathrm{pH}$ on amylase production activities associated with organism growth. The amylase enzyme hydrolyzes the $\alpha-1.4$ glycosidic bonds of starch and maltodextrin randomly from the inside of the polysaccharide molecule to produce several oligosaccharides (sugars) and maltose (Lestari et al. 2013)

The study results provided information on potential amylolytic bacteria found in Ranu Pani, Ranu Regulo, Ranu Grati, and Lake Ngebel. Subsequent research to ascertain the species can be carried out using other gene loci and plasmid characterization (Barcia et al. 2011; Rivera and McGuffin 2015). Bacterial isolates that have been correctly identified need to be undertaken with conservation efforts in the Indonesian Culture Collection (InaCC) Indonesian Institute of Sciences (LIPI). On the other hand, this isolate has the potency to build a microbial bank (microbial culture collection) so that potential amylolytic bacteria can be utilized as an enzyme producer. In microalgae culture, potential amylolytic bacteria is very beneficial because, in addition to being able to degrade the substrate into simple components so that it is easily utilized by algae for its growth, metabolite exchange also makes microalgae more resistant to environmental disturbances so that it can prolong the life of microalgae (Souza 2010; Lian et al. 2018).

In conclusion, bacterial isolates from Ranu Pani, Ranu Regulo, Ranu Grati, and Ngebel Lake have amylase enzyme activity. KN bacterial isolates from Lake Ngebel had the highest amylase enzyme activity of 0.016 units $/ \mathrm{mL}$. Based on the characterization, morphological identification, and molecular techniques (DNA barcoding) with $16 \mathrm{~S}$ rRNA gene sequences of $\mathrm{KN}$ bacterial isolates classified to be the genus Bacillus cereus group with similarity $99.6 \%$ and closely related to Bacillus paramycoides with similarity $99.9 \%$.

\section{ACKNOWLEDGEMENTS}

This research is partly funded by PNBP UM 2019 on the CAMRY PUI scheme with the chair of Sitoresmi Prabaningtyas.

\section{REFERENCES}

Amri E, Widhyastuti N, Artika IM. 2010. Aktivitas amilase bakteri yang diisolasi dari Sumber Air Panas Ciseng Bogor. Jurnal Sainstek 2 (1) 23-33. [Indonesian]

Apriani RR. 2013. Keanekaragaman Zooplankton Berdasarkan Perbedaan Rona Lingkungan Perairan Telaga Ngebel Kabupaten Ponorogo Jawa
Timur. [Hon. Thesis]. Universitas Negeri Malang, malang. [Indonesian]

Arman, Sondana, Fikriyyah, et al. 2019. Screening of amylolytic and cellulolytic yeast from Dendrobium spathilingue in Bali Botanical Garden, Indonesia. Proceeding of the 5th International Symposium on Current Progress in Mathematics and Science. DOI: 10.1063/5. 000.780 .2

Basitoh YK. 2018. Eksplorasi Bakteri Amilolitik Potensial dari Ranu Pani, Ranu Regulo, Ranu Grati, dan Telaga Ngebel. [Hon. Thesis]. Universitas Negeri Malang, Malang. [Indonesian]

Bhattacharjee I, Mazumdar D, Saha SP. 2019. Microbial amylases and their potential application in industries: a review. Parma Innov J 8 (6): 162-170.

Chong SF, Choo R. 2011. Introduction to Bootstrap. Proceedings of Singapore Healthcare 20 (3): 236-240.

Daffonchio D, Cherif A, Borin S. 2000. Homoduplex and heteroduplex polymorphisms of the amplified ribosomal 16S-23S Internal Transcribed Spacers describe genetic relationships in the 'Bacillus cereus group.' Appl Environ Microbiol 66 (12): 5460-5468. DOI: 10.1128/AEM.66.12.5460-5468.2000.

Dipali P, Argit A. 2012. Characterization of amylase producing bacterial isolates. Bull Environ Pharmacol Life Sci 1 (6): 42-47.

Fakhimi N, Gonzalez-Ballester D, Fernández E, Galván A, Dubini A. 2020. Algae-bacteria consortia as a strategy to enhance $\mathrm{H} 2$ production Cells 9: 1353. DOI: 10.1080/07352689.2015.1047712.

Garcillan-Barcia MP, Alvarado A, de la Cruz F. 2011. Identification of bacterial plasmids based on mobility and plasmid population biology. FEMS Microbiol Rev 35: 936-956. DOI: 10.11111/j.15746976.2011.00291.x

Hanner R, Floyd R, Bernard A, Collette BB, Shivji M. 2011. DNA Barcoding of billfishes. Mitochondrial DNA 22 (suppl.): 27-36. DOI: 10.3109/19401736.2011.596833.

Johnson JS, Spakowicz DJ, Hong BY, et al. 2019. Evaluation of $16 \mathrm{~S}$ rRNA gene sequencing for species and strain-level microbiome analysis. Nat Commun 10 (1): 5029. DOI: 10.1038/s41467-01913036-1.

Kaneko T, Ohno T, Ohisa N. 2005. Purification and characterization of a thermostable raw starch digesting amylase from a Streptomyces $\mathrm{sp}$. isolated in a milling factory. Biosci Biotechnol Biochem 69 (6): 1073 81. DOI: $10.1271 /$ bbb.69.1073.

Keharom S, Mahachai R, Chanthai S. 2016. The optimization study of $\alpha$ amylase activity based on central composite design-response surface methodology by dinitrosalicylic acid method. Intl Food Res J 23(1): 10-17.

Kombong H. 2004. Evaluasi daya hidrolitik enzim glukoamilase dari filtrat kultur Aspergillus niger. Jurnal Ilmu Dasar 5: 16-20. [Indonesian]

Lestari P, Richana N, Masriani R, Susilowati DN. 2013. Potential use of an extracellular enzyme of $\alpha$-amylase from indigenous indonesian mesophilic bacteria. J Agric 14: 7-14.

Lian J, Wijffels RH, Smidt H, Sipkema D. 2018. The effect of the algal microbiome on industrial production of microalgae. Microb Biotechnol 11 (5): 806-818. DOI: 10.1111/1751-7915.13296.

Liu Y, Du J, Lai Q, Zeng R, Ye D, Xu J, Shao Z. 2017. Proposal of nine novel species of the Bacillus cereus group. Intl J Syst Evol Microbiol 67 (8): 2499-2508. DOI: 10.1099/ijsem.0.001821.

Miller GL. 1959. Use of dinitrosalicylic acid reagent for determination of reducing sugar. Anal Chem 31 (3): 426-28. DOI: 10.1021/ac60147a030.

Naiola E. 2008. Isolasi dan seleksi mikroba amilolitik dari makanan fermentasi ragi tapai gambutdi Kalimantan Selatan. Berkala Penelitian Hayati 13 (2): 109-114. DOI: 10.23869/bphjbr.13.2.20083.

Raplong HH, Odeleye PO, Hammuel C, Idoko MO, Asanato JI, Odeke EH. 2014. Production of alpha amylase by Bacillus cereus in submerged fermentation. Aceh Intl J Sci Technol 3 (3). DOI: 10.13170/aijst.3.3.1592.

Rivera M, McGuffin P. 2015. The successful search for genetic loci associated with depression.genome medicine. Genome Med 7: 92. DOI: 10.1186.s13073-015-0217-4.

Rossi-Tamisier M, Benamar S, Raoult D, Fournier PE. 2015. Cautionary tale of using $16 \mathrm{~S}$ rRNA gene sequence similarity values in identification of human-associated bacterial species. Intl J Syst Evol Microbiol 65: 1929-1934. DOI: 10.1099/ijs.0.000161.

Sazci A, Erenler K, Radford A. 1986. Detection of cellulolytic fungi by using congo red as an indicator: a comparative study with the 
dinitrosalicyclic acid reagent method. J Appl Bacteriol 61 (6): 559 562. DOI: $10.1111 / \mathrm{j} .1365-2672.1986 . t b 01729 . x$

Silaban S, Marika DB, Simorangkir M. 2020. Isolation and characterization of amylase-producing amylolytic bacteria from rice soil samples. J Physics: Conf Ser 1485: 012006. DOI: 10.1088/17426596/1485/1/012006.

Silitonga R, Lamtiur, Nursyirwani N, Effendi I. 2020. Isolation, identification and sensitivity of amilolitic bacteria from mangrove ecosystem sediment in Purnama Marine Station Dumai on the pathogenic bacteria. Asian J Aquat Sci 2 (3): 257-266. DOI: 10.31258/ajoas.2.3.257-266.

Soeka YS. 2010. Optimasi dan karakterisasi a-amilase dari isola aktinomisetes yang berasal dari Kalimantan Timur. Berita Biologi 10 (3): 361-367. [Indonesian]
Souza PM de. 2010. Application of Microbial-Amylase in Industry - a review. Braz J Microbiol 41: 850-861

Srinivasan R, Karaoz U, Volegova M, MacKichan J, Kato-Maeda M, Miller S, Nadarajan R, Brodie EL, Lynch SV. 2015. Use of 16 S rRNA gene for identification of a broad range of clinically relevant bacterial pathogens. PLoS ONE 10 (2): e0117617. DOI: 10.1371/journal.pone.0117617.

Tomar P, Arunachalam KD, Vinuprakash KC, Thakur H. 2019. Isolation, characterization and molecular identification of bacteria from commercial source using 16s rRNAa sequencing for domestic waste water treatment. Intl J Innov Technol Expl Eng 8 (6): 473.

Uncu AO, Uncu AT, Celık I, Doganlar S, Frary A. 2015. A Primer to Molecular phylogenetic analysis in plants. Crit Rev Plant Sci 34: 454468. DOI: $10.3390 /$ cells9061353. 
Table S1. The value of the activity of the amylase enzyme

\begin{tabular}{|c|c|c|c|c|}
\hline Isolate & Absorbance & $\begin{array}{l}\text { Reducing sugar concentration } \\
(\mathrm{ppm})\end{array}$ & $\begin{array}{c}\text { Amylase enzyme activity } \\
\text { (units } / \mathrm{mL} \text { ) }\end{array}$ & Source \\
\hline G20 & 0.0017 & 0.3855 & 0.0001 & Ranu Grati \\
\hline G6 & 0.0045 & 0.8281 & 0.0003 & Ranu Grati \\
\hline K & 0.0068 & 1.0364 & 0.0004 & Ranu Pani-Regulo \\
\hline B2 & 0.0075 & 1.2969 & 0.0005 & Ranu Pani-Regulo \\
\hline G4 & 0.0128 & 2.1302 & 0.0008 & Ranu Grati \\
\hline $\mathrm{G} 2$ & 0.0168 & 2.75525 & 0.0010 & Ranu Grati \\
\hline $\mathrm{E}$ & 0.0183 & 2.9895 & 0.0011 & Ranu Pani-Regulo \\
\hline $\mathrm{G} 24$ & 0.0215 & 3.4844 & 0.0013 & Ranu Grati \\
\hline DN & 0.0270 & 4.3438 & 0.0016 & Ngebel Lake \\
\hline G & 0.0287 & 4.6042 & 0.0017 & Ranu Pani - Regulo \\
\hline Q & 0.0347 & 5.5417 & 0.0021 & Ranu Pani-Regulo \\
\hline $\mathrm{T}$ & 0.0353 & 5.6458 & 0.0021 & Ranu Pani-Regulo \\
\hline $\mathrm{L} 2$ & 0.0370 & 5.9063 & 0.0022 & Ranu Pani - Regulo \\
\hline $\mathrm{G} 23$ & 0.0422 & 6.7136 & 0.0025 & Ranu Grati \\
\hline $\mathrm{R}$ & 0.0480 & 7.6250 & 0.0028 & Ranu Pani-Regulo \\
\hline A & 0.0505 & 8.0156 & 0.0030 & Ranu Pani-Regulo \\
\hline G10B & 0.0525 & 8.3281 & 0.0031 & Ranu Grati \\
\hline $\mathrm{B}$ & 0.0555 & 8.7969 & 0.0033 & Ranu Pani-Regulo \\
\hline $\mathrm{C}$ & 0.0563 & 8.9270 & 0.0033 & Ranu Pani-Regulo \\
\hline $\mathrm{N}$ & 0.0583 & 9.2396 & 0.0034 & Ranu Pani-Regulo \\
\hline $\mathrm{EN}$ & 0.0600 & 9.5000 & 0.00352 & Ngebel Lake \\
\hline $\mathrm{H}$ & 0.0627 & 9.9167 & 0.0037 & Ranu Pani-Regulo \\
\hline I & 0.0630 & 9.9688 & 0.0037 & Ranu Pani-Regulo \\
\hline B1 & 0.0722 & 11.4010 & 0.0042 & Ranu Pani-Regulo \\
\hline $\mathrm{X}$ & 0.0803 & 12.6770 & 0.0047 & Ranu Pani-Regulo \\
\hline G14 & 0.0820 & 12.9375 & 0.0048 & Ranu Grati \\
\hline $\mathrm{M}$ & 0.0840 & 13.2500 & 0.0049 & Ranu Pani-Regulo \\
\hline $\mathrm{PN}$ & 0.0912 & 14.3698 & 0.0053 & Ngebel Lake \\
\hline $\mathrm{H} 2$ & 0.0940 & 14.8125 & 0.0055 & Ranu Pani-Regulo \\
\hline $\mathrm{J}$ & 0.0985 & 15.5156 & 0.0057 & Ranu Pani-Regulo \\
\hline $\mathrm{O}$ & 0.1195 & 18.7969 & 0.0070 & Ranu Pani-Regulo \\
\hline G36 & 0.1252 & 19.6823 & 0.0073 & Ranu Grati \\
\hline $\mathrm{U}$ & 0.1328 & 20.8802 & 0.0077 & Ranu Pani-Regulo \\
\hline G30 & 0.1360 & 21.3750 & 0.0079 & Ranu Grati \\
\hline G1 & 0.1425 & 22.3906 & 0.0083 & Ranu Grati \\
\hline G32 & 0.1465 & 23.0156 & 0.0085 & Ranu Grati \\
\hline GN & 0.1468 & 23.0677 & 0.0085 & Ngebel Lake \\
\hline $\mathrm{TN}$ & 0.1507 & 23.6667 & 0.0088 & Ngebel Lake \\
\hline $\mathrm{L} 1$ & 0.1555 & 24.4219 & 0.0090 & Ranu Pani-Regulo \\
\hline IN & 0.1610 & 25.2813 & 0.0094 & Ngebel Lake \\
\hline FN & 0.1632 & 25.6198 & 0.0095 & Ngebel Lake \\
\hline $\mathrm{NN}$ & 0.1645 & 25.8281 & 0.0096 & Ngebel Lake \\
\hline $\mathrm{P}$ & 0.1655 & 25.9844 & 0.0096 & Ranu Pani - Regulo \\
\hline G13 & 0.1695 & 26.6094 & 0.0099 & Ranu Grati \\
\hline $\mathrm{L}$ & 0.1745 & 27.3906 & 0.0101 & Ranu Pani - Regulo \\
\hline VN & 0.1750 & 27.4688 & 0.0102 & Ngebel Lake \\
\hline $\mathrm{D}$ & 0.1793 & 28.1458 & 0.0104 & Ranu Pani - Regulo \\
\hline G18 & 0.1910 & 29.9688 & 0.0111 & Ranu Grati \\
\hline G33 & 0.2183 & 34.2395 & 0.0127 & Ranu Grati \\
\hline $\mathrm{HN}$ & 0.2567 & 40.2292 & 0.0149 & Ngebel Lake \\
\hline V & 0.2635 & 41.2969 & 0.0153 & Ranu Pani Regulo \\
\hline $\mathrm{KN}$ & 0.2730 & 42.7813 & 0.0158 & Ngebel Lake \\
\hline
\end{tabular}

